\title{
Some experience in numerical modelling of unsaturated slope instabilities
}

\author{
Josif Josifovski $^{1}$ and Stanislav Lenart ${ }^{2}$ \\ ${ }^{1}$ Faculty of Civil Engineering, Ss. Cyril and Methodius University, Skopje, Republic of Macedonia \\ 2 Slovenian National Building and Civil Engineering Institute, Ljubljana, Slovenia
}

\begin{abstract}
In the past couple years, the region of South-East Europe is subjected to gust rainfall events activating many landslides which cause significant material and human losses. To revaluate the existing risk maps and set new standards some old case histories are revaluated. This paper presents two case histories of landslide instabilities subjected to excess climatic perturbations, gust rainfall, namely the «Stanjevci» cut-slope near the railway line in North-East of Slovenia; and the «Ramina» a natural landslide in urban area near the city of Veles in Central Macedonia. They are briefly described later to be analysed using coupled thermo-mechanical calculations. They are subjected to specific short and gusting rainfall considered as possible trigger. Hence, van Genuchten's hydraulic model is used in combination with elastoplastic material models. The results are summarized with critical comments regarding the mathematical formulation used to describe atmospheric-soil interaction and the influence of different aspects on the accuracy is discussed briefly.
\end{abstract}

\section{Introduction}

Many new landsliding occurrences have been recorded in the past couple of years, in South-East Europe as a consequence of climate change and storm rainfall. If this trend continues, the landslides could cause significant devastation to infrastructure and human life. This requires that the existing risk maps to be revaluated thoroughly, based on advanced calculations that include the effects of saturation or partial saturation of the soil on slope stability [3].

The behaviour of the slopes is controlled by their hydromechanical conditions and by soil-atmosphere interaction. The pore water pressure changes within a slope in some cases significantly reducing the soil strength. Climatic factors such as precipitation, evapotranspiration and runoff may also have a substantial impact on slope stability.

In terms of numerical modelling, the stability analysis of partially saturated slopes is a complex problem with many variables. The more advanced approaches require input data obtained from the Soil Water Retention Curve (SWRC) and the unsaturated hydraulic conductivity function. Moreover, the time dependent hydromechanical behaviour of the soil should be described in a coupled format, taking both deformation and groundwater flow into account, in which mixed equations of displacement and pore pressure, called, have to be solved simultaneously in a coupled hydro-mechanical approach [9].

Advanced numerical model with definitions of climatesoil system is used to determine the rainfall influence on the slope failure. Conclusive discussion of the simulated

\footnotetext{
a Corresponding author: jjosifovski@gf.ukim.edu.mk
}

hydro-mechanical numerical effects with suggestions for possible model improvements is presented at the end.

\section{Site descriptions}

The analysis considers two different slope instabilities, namely, the «Stanjevci» cut-slope near the railway line in North-East of Slovenia; and the «Ramina» a natural landslide in urban area near the city of Veles in Central Macedonia. In the following text they are briefly described through their geo-hydro-mechanical characteristics.

\subsection{The «Ramina» case history}

Macedonia is situated on the southern part of Balkan Peninsula as mountainous country $79 \%$ are hills and mountains with mean altitude of $832 \mathrm{~m}$ with large areas of erodible soils and rocks, steep slopes. Most hillslopes are composed of crystalline rocks (gneiss, mica-schists, other schists), sandstones, lacustrine and river deposits all of them highly erodible. Mean topographic slope of the country is $13.5^{\circ}$ with $39.5 \%$ of the area steeper than $15^{\circ}[5]$.

The influence of Continental and Mediterranean climate in Macedonia unequally spreads the precipitations through throughout the year with intensity between 400 $900 \mathrm{~mm} /$ year, thus long-time arid periods from (summerautumn) and short wet seasons exist. According to the precipitation data for the period 2007-2010 there is evident increase in the precipitation (Table 1). 
The «Ramina» is natural landslide located in highly urbanized hilly area of city Veles, Macedonia, on the left bank of the river Vardar. In the past it had been reactivated several times, last time in 2002 with major deformations leading to severe damage of the infrastructure and buildings.

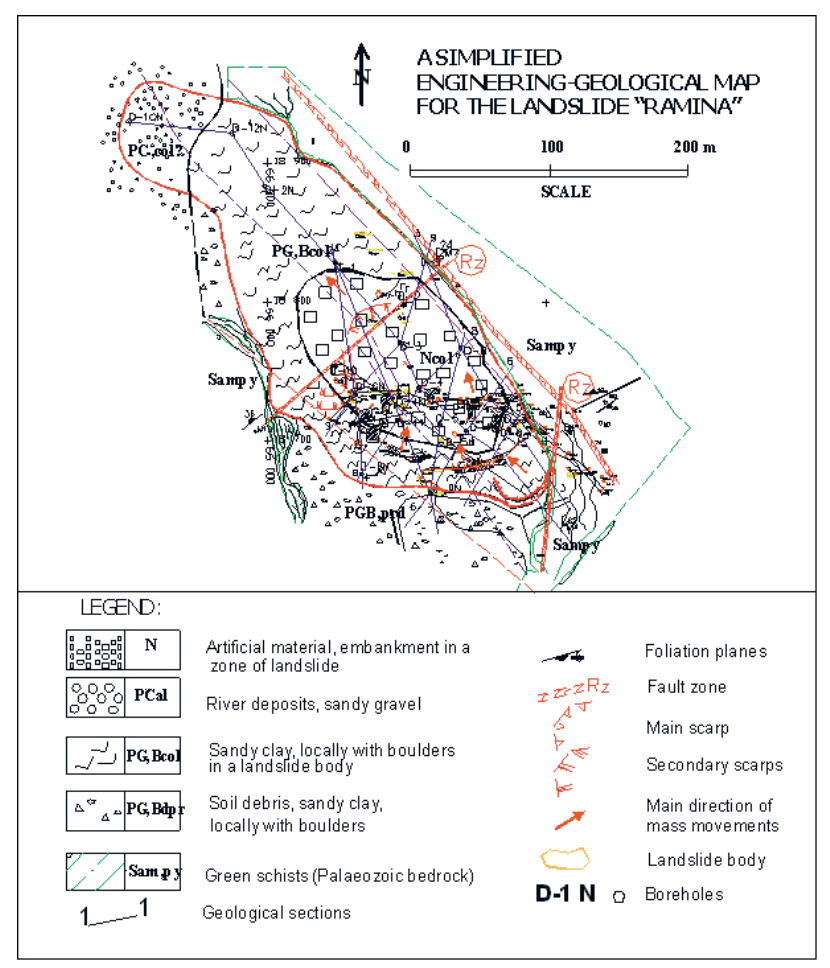

Figure 1. Simplified Engineering Geological map of «Ramina» landslide.

A season of gust rainfall in period from December to March averages with monthly precipitation of around 140 $\mathrm{mm} / \mathrm{month}$ or as maximal daily precipitation of $70 \mathrm{~mm}$. The elevation of the slope is around $1000 \mathrm{~m}$ above sea level sited on the transition of relatively steep mountain slopes to a river valley. Actually, it is attacked by a surface and ground water from wider catchment area, moreover there is no vegetation to reduce the effects of heavy rainfall events. The average slope angle is around $15^{\circ}$ and maximal $22^{\circ}$. The landslide is about $500 \mathrm{~m}$ long with average width of about $100 \mathrm{~m}$ and height of $95 \mathrm{~m}$ (Fig. 1). The estimated maximum depth of the shear zone is $24 \mathrm{~m}$. The sliding system is comprised of two parts (Fig.2), the «upper» with a length of $350 \mathrm{~m}$, width $110 \mathrm{~m}$, height $60 \mathrm{~m}$ and «lower» with length of $200 \mathrm{~m}$, width 90 $\mathrm{m}$, height $35 \mathrm{~m}$ and depth up to $18 \mathrm{~m}$. The total area of the landslide is estimated to be $37,600 \mathrm{~m}^{2}$ with around $475,200 \mathrm{~m}^{3}$ of sliding mass, ranking it as the biggest in the Balkans, and possibly in South East Europe [4].

Table 1. Precipitations in the analysed case histories.

\begin{tabular}{|c|c|c|c|c|}
\hline Site & \multicolumn{2}{|c|}{ Stanjevci, SLO } & \multicolumn{2}{c|}{ Ramina, MK } \\
\hline Year & $\begin{array}{c}\text { Precip. } \\
(\mathrm{mm} / \mathrm{y})\end{array}$ & $\begin{array}{c}\text { Max precip. } \\
(\mathrm{mm} / \mathrm{month})\end{array}$ & $\begin{array}{l}\text { Precip. } \\
(\mathrm{mm} / \mathrm{y})\end{array}$ & $\begin{array}{c}\text { Max precip. } \\
(\mathrm{mm} / \mathrm{month})\end{array}$ \\
\hline 2000 & 719.1 & 44.4 & - & - \\
\hline 2001 & 595.2 & 30 & - & - \\
\hline 2002 & 847.5 & 79.2 & - & - \\
\hline 2003 & 554.1 & 33 & - & - \\
\hline 2004 & 1032.4 & 38 & - & - \\
\hline 2005 & 851.2 & 79.2 & - & - \\
\hline 2006 & 828.5 & 75 & - & - \\
\hline 2007 & 895.4 & 79.2 & 498.7 & 140.0 \\
\hline 2008 & 929.7 & 52 & 438.5 & 78.5 \\
\hline 2009 & - & - & 642.6 & 104.3 \\
\hline 2010 & - & - & 900.0 & 108.2 \\
\hline Avg & $\mathbf{8 0 5 . 9}$ & $\mathbf{5 6 . 7}$ & $\mathbf{6 2 6 . 9}$ & $\mathbf{1 0 7 . 7}$ \\
\hline
\end{tabular}

Figure 2. Typical geological profile of «Ramina» landslide.

The geotechnical investigations indicate a sliding zone on the contact between weathered bedrock (Palaeozoic amphibolitic schists, highly foliated and faulted) and low plasticity claylike mass. The hydrogeological conditions indicate that the zones with increased water contents are related to the sliding zone. Also, a slight sub-artesian effect is found in almost all boreholes [5]. The GWL has been detected at $8 \mathrm{~m}$ of depth while in the lower part it was around $2 \mathrm{~m}$ below the terrain.

\subsection{The «Stajcevci» case history}

Slovenia is a southern Central European country located at the junction of three important geotectonic units: the Alps at the north, the Dinaric Alps at the south and the Pannonian Basin at the east. The territory of Slovenia is mostly mountainous with a mainly continental climate. Additionally, coastal part of the country has sub- 
Mediterranean climate and the north-western part has an Alpine climate. Diversity in every aspects of nature is a trade mark of country. Slovenia is located in temperate latitudes. The climate is also influenced by the variety of relief, and the influence of the Alps and the Adriatic Sea. In the Northeast, the continental climate type with greatest difference between winter and summer temperatures prevails. In the coastal region, there is subMediterranean climate. The effect of the sea on the temperature rates is visible also up the Soča valley, while a severe Alpine climate is present in the high mountain regions. There is a strong interaction between these three climatic systems across most of the country [13]. Precipitation varies across the country as well. Average rainfall depth exceeds $3,500 \mathrm{~mm} /$ year in some Western regions and dropping down to $800 \mathrm{~mm} / \mathrm{year}$ in northeastern part of the country. In the winter, also snow is quite frequent.

A seemingly almost routine railway cut slope, beside railway tunnel «Stajcevci» on the railway line between Murska Sobota and Hodoš in northeastern part of Slovenia, was constructed in the first half of early year 2000. Tunnel and cut slope passed through Pliocenne soil layers: sand with gravel, silt and clay in subhorizontal orientations [6]. Although the cut slope was made in gentle slope not steep, stability problems arose already during the construction works, particularly due to saturated silty-sand layers covered by clay and low cohesion of saturated contact between clay and silty-sand. Stanjevci tunnel and the cut slope in its vicinity are located in the northern, central part of the Goričko hills in north-eastern Slovenia, that are dominated by sediments of the middle Pliocene, both marine and brackish, as well as fluvial and lacustrine origin. Generally, sediments of Goričko hills belong to tectonic zone of the Pannonian basin. Unstable cut slope above railway line near Stanjevci tunnel is located in the middle Pliocene sediments PL2, which passes in the middle Miocene (tortonium) layers that lie discordantly on the Paleozoic metamorphic rocks. The estimated thickness of Tertiary sediments in the area of the landslide is approximately $2000 \mathrm{~m}$. General dip of the layers of the Tertiary sediments and contact with Paleozoic rocks is approximately $10^{\circ}$ towards the SSE.
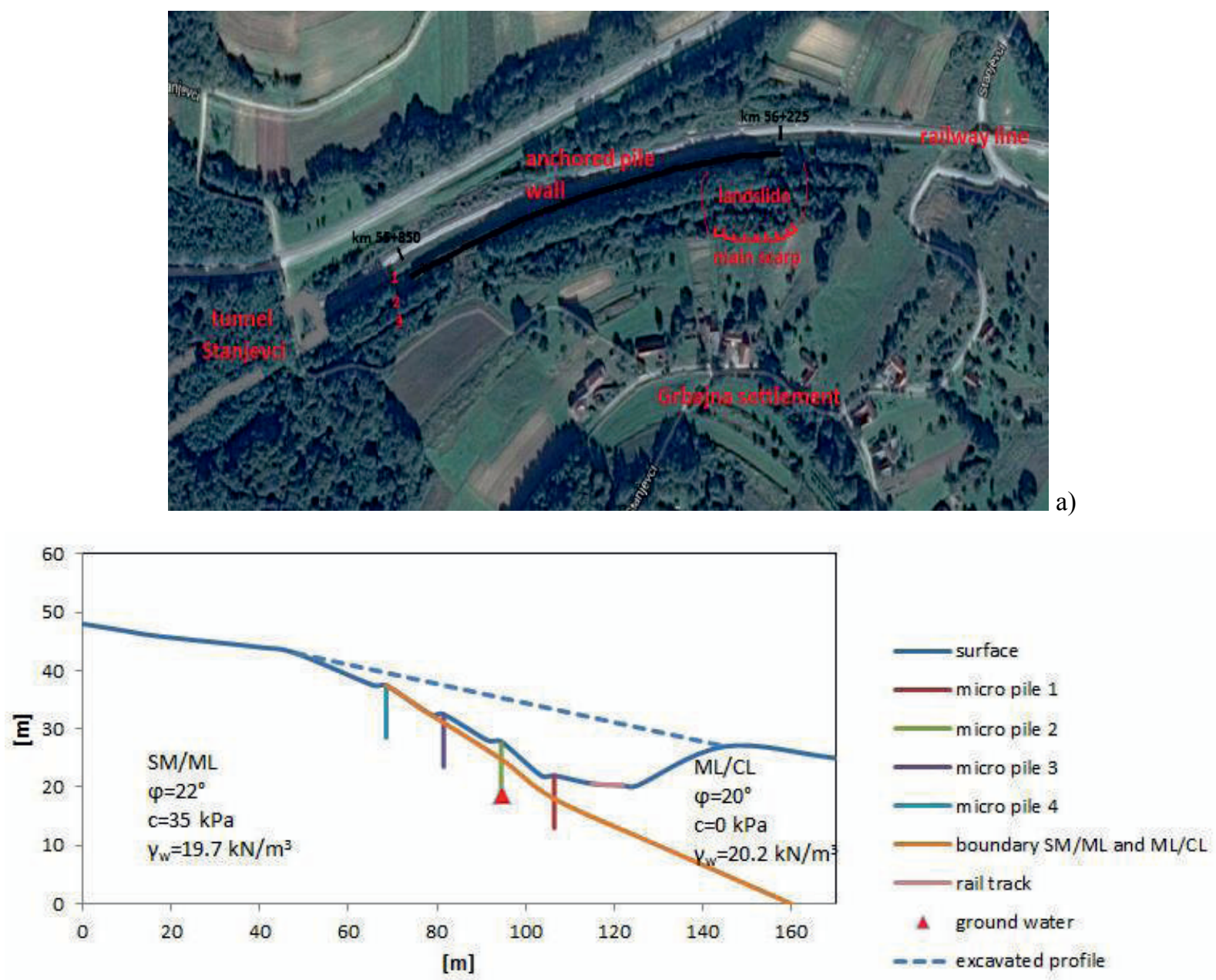

b)

Figure 3. (a) The «Stajcevci» cut-slope: (a) Plan view on cut-slope near the tunnel and (b) Simplified geological profile of the excavated slope. 
The landslide is located on the hillside, where a cut slope was made with slope direction towards north. The excavation pit is in the deepest part more than $30 \mathrm{~m}$ deep. At the time of the pit excavation an extensive geotechnical investigation was performed to support stabilization measures. In the vicinity of the landslide there are no recorded tectonic structures. The precipitation data [12] in the period 2000-2008 was taken with maximal values in the analysis (Table 1).

\section{Numerical modelling}

To analyse mechanical behaviour of saturated or partially saturated soils by means of numerical method e.g. finite element method, in proper manner, it is necessary to take into account both deformation and groundwater flow. For time dependent behaviour, this leads to mixed equations of displacement and pore pressure, called coupled hydromechanical approach, which have to be solved simultaneously [2].

The task was to perform a coupled hydro-mechanical analysis of slope stability on the presented case histories. The calculation was performed using the finite element software Plaxis [1] which enables fully coupled hydromechanical analysis. This type of analysis is able properly to evaluate the effects of rainfall and water infiltration on the slope stability. The shear strength of the unsaturated soil has been examined based on effective stress concept considering suction. The finite element method with shear strength reduction technique was employed to evaluate the stability using the factor of safety (FoS). For the soil material an elastic-perfectly plastic small strain Mohr-Coulomb (MC) model was employed with special attention put on definition of mechanical and hydraulic parameters critical for realistic simulation. According to the available data, a conservative choice has been taken. For simplicity a homogeneous profile is assumed with soil parameters given in Table 2 .

Table 2. Soil material parameters for MC model.

\begin{tabular}{|c|c|c|}
\hline Case (material) & $\begin{array}{c}\text { Ramina } \\
\text { (Sandy-Clay) }\end{array}$ & $\begin{array}{c}\text { Stajcevci } \\
\text { (Clay) }\end{array}$ \\
\hline $\begin{array}{c}\text { Unit weight } \\
\gamma\left(\mathrm{kN} / \mathrm{m}^{3}\right)\end{array}$ & 20.14 & 20.2 \\
\hline $\begin{array}{c}\text { Eff. friction angle } \\
\phi^{\prime}\left({ }^{0}\right)\end{array}$ & 23 & 22 \\
\hline $\begin{array}{c}\text { Eff. Cohesion } \\
c^{\prime}(\mathrm{kPa})\end{array}$ & 12 & 15 \\
\hline $\begin{array}{c}\text { Eff. Poisson's } \\
\text { ratio } v^{\prime}(/)\end{array}$ & 0.32 & 7000 \\
\hline $\begin{array}{c}\text { Elastic modulus } \\
E^{\prime}(\mathrm{kPa})\end{array}$ & 10000 & 0.30 \\
\hline
\end{tabular}

For definition of the hydraulic models at the Slovenian National Building and Civil Engineering Institute tensiometer laboratory test were performed to determined the suction in the material samples for different water content. Through the measured data a nonlinear SWRC fitting (fig.4) after UNSODA [8] database was made.

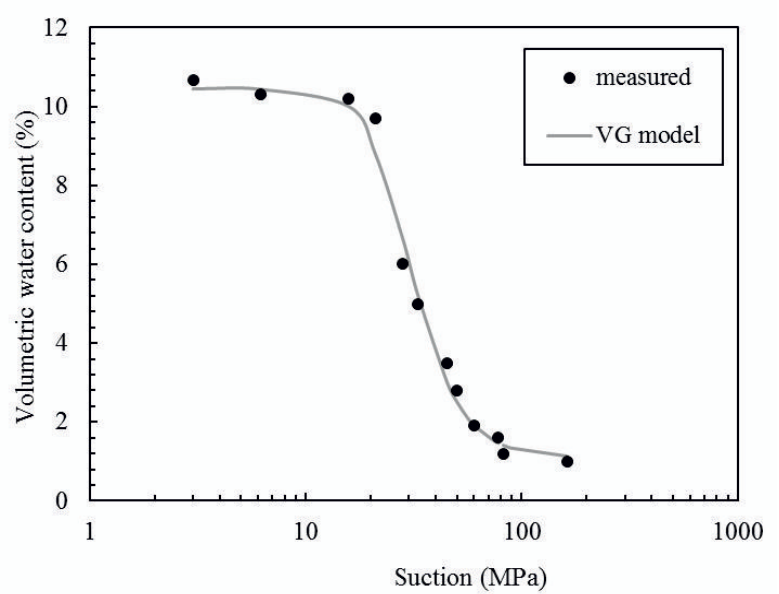

a)

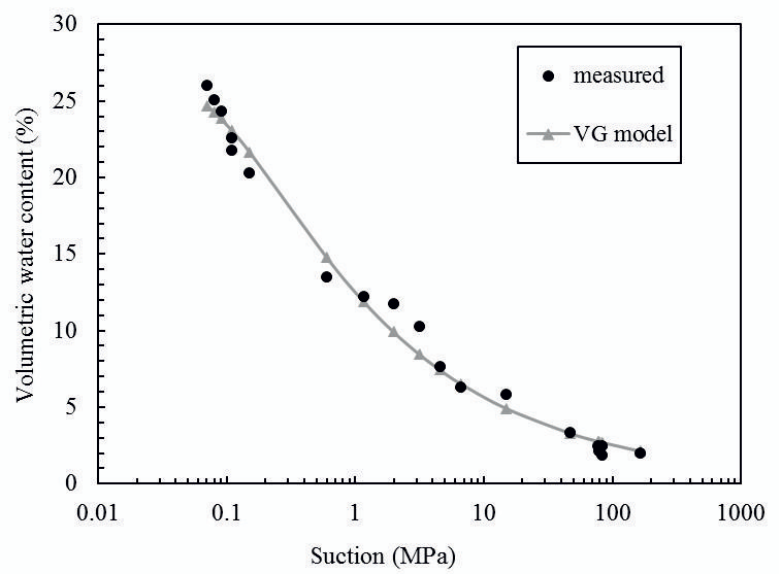

b)

Figure 4. SWRC of a) Sandy-Clay from The «Ramina» and b) Clay from «Stajcevci» cut-slope

The hydraulic model is defined by of Van Genuchten model parameters [12] given in Table 3.

Table 3. Hydraulic data of Van Genuchten model.

\begin{tabular}{|c|c|c|c|c|c|c|}
\hline Case & Soil & $\begin{array}{c}\mathbf{k}_{\text {sat }} \\
(\mathrm{m} / \mathrm{s})\end{array}$ & $\begin{array}{c}\boldsymbol{\theta}_{\mathbf{s}} \\
(-)\end{array}$ & $\begin{array}{c}\theta \mathbf{r} \\
(-)\end{array}$ & $\begin{array}{c}\boldsymbol{\alpha} \\
(1 / \mathrm{kPa})\end{array}$ & $\begin{array}{c}\mathbf{n} \\
(-)\end{array}$ \\
\hline Ramina & $\begin{array}{c}\text { Sandy- } \\
\text { Clay }\end{array}$ & $1 \mathrm{E}-6$ & 10.45 & 1.1 & 0.355 & 4.17 \\
\hline Stajcevci & Clay & $1 \mathrm{E}-8$ & 27.8 & 0.001 & 9.5 & 1.35 \\
\hline
\end{tabular}

In the «Ramina» case a constant rainfall infiltration is assumed to be $10 \mathrm{~mm} / \mathrm{h}$ on the free surface plus additional $1 \mathrm{~m}^{3} / \mathrm{h}$ on left inflow boundary. Similarly, in the «Stajncevci» case the precipitation of $15 \mathrm{~mm} / \mathrm{h}$. Both simulated scenarios run for time period of $12 \mathrm{~h}$. The interaction between atmosphere-vegetation was not considered nor the temperature effects. Mesh updating has been performed, as it is often the case when due to deformation the finite elements are moving from saturated to unsaturated zone and vice versa. 


\section{Results}

The analysis produced wide range of results clearly depicting the influence of the heavy rainfall on the hydromechanical material parameters. Generally, the position of phreatic level and the distribution of pore water pressure are governed climate conditions (groundwater flow boundary conditions) with suction above phreatic level where with time in the case of downward flux (i.e. precipitation) suction decreases (and degree of saturation increases) and the water level rises. Below are presented the results of the coupled flow-deformation analysis, the development of suction and displacement on the «Ramina» landslide are presented in Figure 4.
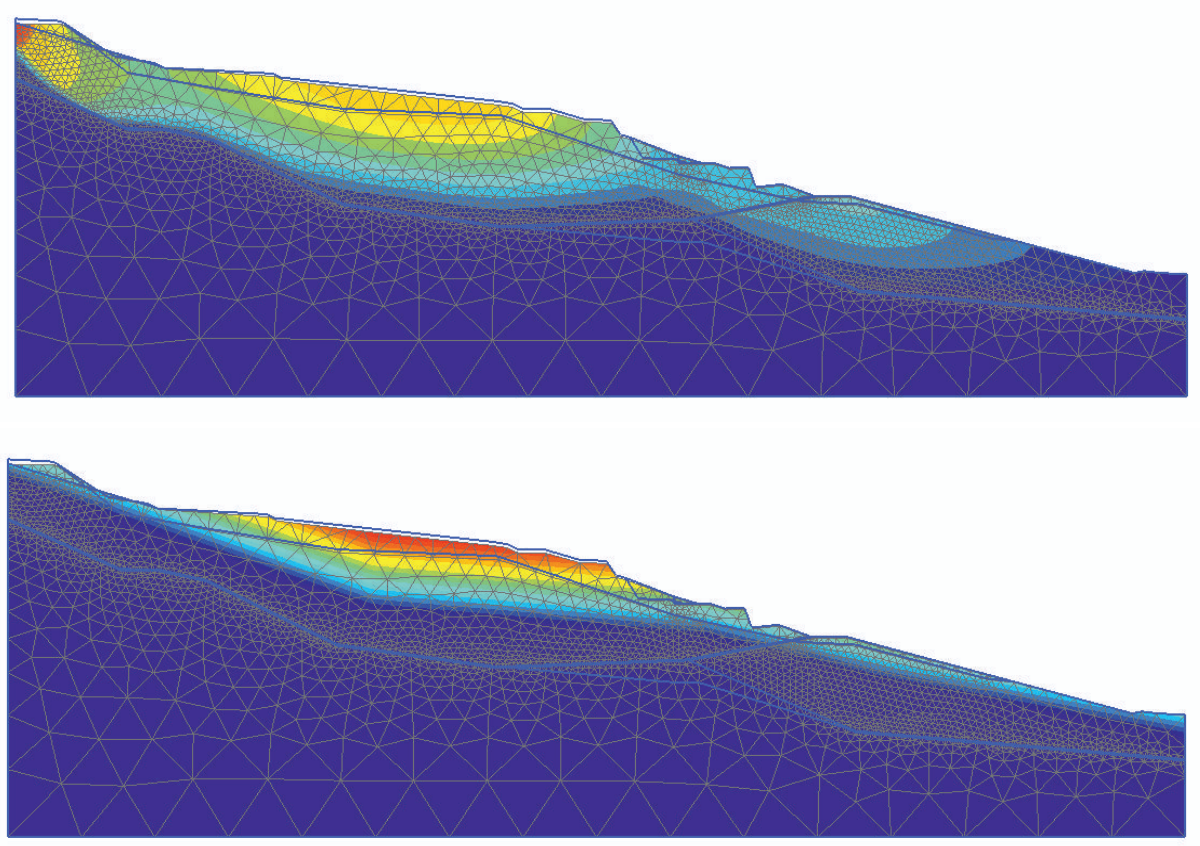

a)

Figure 5. The «Ramina» results: (a) Total displacements and (b) Suction profile.

The mass sliding had occurred just before $12 \mathrm{~h}$ of rainfall triggering displacement of $0.8 \mathrm{~m}$ at the top of the landslide. The sliding mechanism had developed first in the upper part triggered by in PWP build-up establishing different GWL in the upper and lower part. The critical shear strength had been reached in the upper part of the landslide with PWP rise of about $50 \%$ at the bedrock interface but also with maximum suction of $169.7 \mathrm{kN} / \mathrm{m}^{2}$ at top of the layer. Realistic simulation of the sliding mass behaviour (Figure 5) has been obtained where after the registered sliding a mass stabilization occurred defined by $\mathrm{FoS}=1,3$.

In the same manner the results of «Stajcevci» cut-slope are presented in Figure 5.

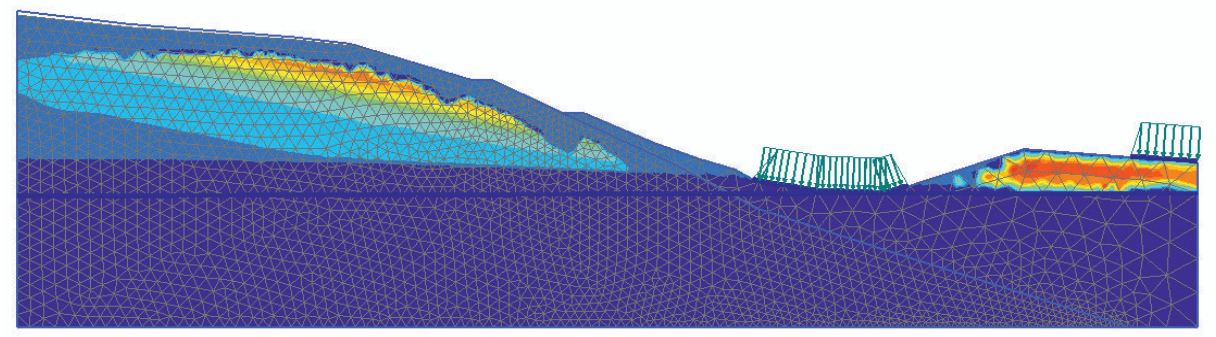

a)

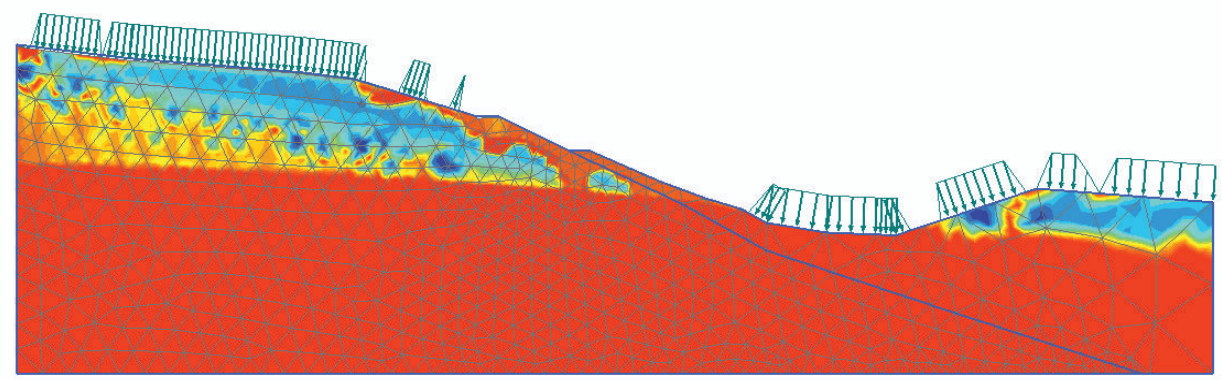

b)

Figure 6. The «Stajcevci» results: (a) Suction and (b) Saturation profile. 
The simulation of hydraulic conditions leads to a saturation profile with a raise in GWL producing $20 \%$ increase of PWP and reducing the suction to $12.81 \mathrm{kN} / \mathrm{m}^{2}$ (Figure 6). This is followed by a global displacement with maximal displacement of $0.6 \mathrm{~m}$ being realized before the $12 \mathrm{~h}$ of precipitation. The ultimate limit state is and global cut-slope destabilization is ensured by $\mathrm{FoS}=1,22$.

\section{Conclusion}

The consequences of climate change on landslide rate, size and frequency are difficult to predict because they depend on a range of variables. The precipitation (mostly in rainfall) is among the most important factors especially severe storm would cause flash floods with intense erosion and landsliding. In addition to the above direct influences, the indirect impact of climate change on landslide will be exerted through changes of vegetation cover, quality and density, runoff, overland flow and oversaturation would increase raising the rate of erosion and frequency of landslides. Rainfall is often the main factor for landslinding. The modelling has shown that suction responses to rainfall vary on a number of different timescales [10]. On shorter timescales (ranging from minutes to hours and days) heavy rainfall which was of primary interest in this study produced very interesting results. The rainfall infiltration effects in the literature [11] are usually critical for shallow landslides, but here it proven that also the deep sited landslides with high GWL could be destabilized.

In the analysis it has been evaluated the influence in the sense of infiltration and duration of rainfall on the both slopes. It was proven that relatively short $(12 \mathrm{~h})$ but gust rainfall $(10-15 \mathrm{~mm} / \mathrm{h})$ could have a significant influence on the overall (global) stability. According to the statistics this type of events are to be expected frequently. Other modelling aspects of climate-vegetation-soil system such as: influence of cracks and fissures, root water uptake were not considered, thus there are still but a few improvements in this model.

\section{Acknowledgements}

This paper is result of collaboration between Faculty of Civil Engineering in Skopje and Slovenian National Building and Civil Engineering Institute from Ljubljana in the framework of COST action TU1202 - a European network which addresses the impacts of climate change on engineered slopes for infrastructure activities. The research and knowledge transfer was enabled through short term scientific missions adequately supported.

\section{References}

1. Plaxis bv. Plaxis 2D AE. Scientific Manuel (2012).
2. V. Galavi, Internal report: Groundwater flow, fully coupled flow deformation and undrained analysis in Plaxis $2 d$ and 3D. (2010)

3. D. Hughes, Md Rajibul Karim, K. Briggs, S. Glendinning, D. Toll, T. Dijkstra, W. Powrie and N. Dixon. XVI European Conference on Soil Mechanics and Geotechnical Engineering, At Edinburgh A Comparison of numerical modelling techniques to predict the effect of climate on infrastructure slopes, (2015).

4. J. Josifovski, S. Gjorgjevski, B. Susinov. 1st Regional Symposium on Landslides in the AdriaticBalkan Region with 3rd Workshop of the JapaneseCroatian Project on 'Risk Identification and LandUse Planning for Disaster Mitigation of Landslides and Floods in Croatia. Ramina Landslide from a Natural Hazard to Remediation. Zagreb (2013)

5. M. Jovanovski, I. Peshevski, B. Markoski, S. Petrusheva, B. Susinov. 1st Regional Symposium on Landslides in the Adriatic-Balkan Region with 3rd Workshop of the Japanese-Croatian Project on 'Risk Identification and Land-Use Planning for Disaster Mitigation of Landslides and Floods in Croatia. Landslide Inventory Map of the Republic of Macedonia, statistic sand description of main historical and slide events. Zagreb (2013).

6. S. Lenart. Slovenian National Building and Civil Engineering Institute Slovenia, Section for Earthquake Engineering. Deformation characteristics of lacustrine carbonate silt in the Julian Alps. Volume 26, Issues 2-4. 131-142 (2006).

7. S. Lenart, K. Fifer Bizjak. Proceedings of the 3rd International Conference on Landslides, Slope Stability and the Safety of Infra-Structures, Singapore: Ci-Premier Conference Organisation, Numerical analysis of a seismic response of the Stože landslide, 325-331 (2002).

8. K. Seki, Hydrol. Earth Syst. Sci. Discuss., 4: SWRC fit - a nonlinear fitting program with a water retention curve for soils having unimodal and bimodal pore structure. 407-437 (2007).

9. SAFELAND - Living with landslide risk in Europe: Assessment, effects of global change, and risk management strategies.

10. F. Casini, V. Serri, and S. M. Springman. Canadian Geotechnical Journal, 50(1): Hydromechanical behaviour of a silty sand from a steep slope triggered by artificial rainfall: from unsaturated to saturated conditions, 28-40 (2015).

11. S.M. Springman, C. Jommi and P. Teysseire. Géotechnique, 53(1). Instabilities on moraine slopes induced by loss suction: a case history, 3-10 (2003).

12. Th. M. van Genuchten. Soil Science Society of American Journal, 44: A closed-form equation for predicting the hydraulic conductivity of unsaturated soils. 892-898 (1980).

13. ARSO, National Meteorological Service of Slovenia - Archive. www.meteo.si (2015). 